FARKAS TAMÁS - SLÍZ MARIANN szerk., Tulajdonnevek és szótárak. ELTE Magyar Nyelvtudományi és Finnugor Intézet - Magyar Nyelvtudományi Társaság,

Budapest, 2020. 109-130. DOI: 10.26546/4892373.7

\title{
Tulajdonnevek a kulturális szótárakban
}

1. Egy speciális szótártípus: a kulturális szótár. Az általános lexikográfiai szakirodalomban a szótárakat különböző dichotómiák alapján szokták osztályozni: egy- vagy többnyelvü, szinkrón vagy diakrón, általános vagy szaknyelvi, a standard nyelvet vagy egy-egy nyelvváltozatot bemutató (nyelvjárási, csoportnyelvi stb., vö. MAGAY 2015: 10). A nyelvészeti szótárak osztályozása a bennük található lexikai egységek alapján is lehetséges: pl. archaizmusokat, neologizmusokat, idegen szavakat, szakszavakat, tabuszavakat, eufémizmusokat feldolgozó szótárak.

A kulturális szótárak a felsorolt szempontok szerint deskriptívek, tipikusan kétnyelvüek, a kiválasztott szókincs szinkrón bemutatására törekednek, és speciálisak, hiszen a szókincsnek csak egy meghatározott szeletére fókuszálnak. Terjedelmükben korlátozottak (azaz nem teljesek; vö. MAGAY 2015: 11). Tartalmukban inkább az enciklopédiákhoz állnak közel, hiszen szócikkeikben kevés a nyelvi, annál több a kulturális információ. MAGAY TAMÁS (2015: 15) szótárosztályozási rendszerében a kulturális szótárak a kétnyelvü, (enciklopédikus elemekkel bővített vagy) enciklopédikus, illetve hibrid szótárak kategóriájába tartozhatnak.

FÁBIÁN ZSUZSANNA (2015: 21) a terminológiai sokféleségből kiemeli az enciklopédikus szótár fogalmát, amely esetében „a szótárba »oltották be« az enciklopédiát”. Az enciklopédikus szótár fogalma annál is inkább találó lehet a kulturális szótárak esetében, mert ezekben a szerzők a tulajdonnevekkel kapcsolatban enciklopédikus ismereteket (is) közölnek (vö. FÁBIÁN 2015: 29).

A magyarországi kulturális szótárak a jelenleg ismert formájukban leginkább az országspecifikus lexikonokra vagy útikönyvekre hasonlítanak (pl. a közel 1300 oldalas, német nyelvü Franciaország-lexikonra [SCHMIDT et al. 2006]). A kulturális szótárakban ugyanis elsősorban a címszóval jelzett fogalom definíciója, leírása, körülírása található.

A Corvina Kiadónak a 21. század küszöbén indított sorozatában angol-magyar (BART 1998, 2002, 2018), amerikai-magyar (BART 2000, 2017), japán-magyar (GY. HORVÁTH 1999, 2018), német-magyar (GYÖRFFY 2003, 2018), francia-magyar (ÁDÁM 2005), orosz-magyar (SOPRONI 2008), olasz-magyar (SZTANÓ 2008), sőt egy nyelv(terület) helyett egy városra fókuszáló (római) kulturális szótárt (LUKÁCS 2018) is találunk. ${ }^{1}$ Fordított irányú, magyar kulturális szótárak is születtek francia, angol és német nyelven (BART 2005, 2015, 2016).

A kulturális szótárak kiadásába más (határon túli) kiadók is bekapcsolódtak. BENŐ ATTILA (2009) román-magyar, PÉNTEK JÁNOSsal közösen pedig (PÉNTEK-BENÖ 2013) magyar-román kulturális szótárt is megjelentetett. BALOGH F. ANDRÁs ugyanebben a sorozatban német-magyar (2017) kulturális szótárt adott közre, amelyben a kisebbségi német népcsoportok (svábok, szászok, cipszerek stb.) kultúrája és szókincse jelenik meg.

\footnotetext{
${ }^{1}$ Az említett évszámok az egyes kiadásokra utalnak. A tanulmány mindegyik szótárnak csak a legutóbbi kiadását vizsgálja a továbbiakban.
} 
Kissé meglepő módon magyar szerzőtől, ÓDOR LÁSzLÓtól jelent meg német nyelvü svájci kulturális szótár a nyelvközösség nem svájci részének címezve (ÓDOR 2010), amelyben a szerző a svájci németek és nyelvhasználatuk jellegzetességeit foglalja össze kb. 2000 rövid szócikkben. A szerző később a német kulturális szótárakkal rokon müvet is megjelentetett (ÓDOR 2016) - immár a teljes német nyelvterületről, esszészerüvé duzzadt szócikkeket füzve össze.

A müfaj újszerüségének megfelelően a szakirodalomban alig találunk említést a kulturális szótárak mibenlétéről; ezek közt említendő LUKÁCS ANDRÁS angol, német, francia és olasz szótárakat összehasonlító elemzése (2010).

A kulturális szótárak - más speciális szótárakhoz hasonlóan - címükben utalnak arra, hogy miben térnek el az általános szótáraktól: „kulturálisan” meghatározott szavakat, kifejezéseket tartalmaznak. „A nyelv és kultúra számos különböző szegmensét felölelö címszóállományt nehéz összefoglalóan jellemezni. A kulturális szótárak szerzőinek koncepciójához valószínüsíthetően akkor járunk a legközelebb, ha a lexikográfiai és fordítástudományi szaknyelvben is ismert kultúra-specifikus szavak felöl közelítjük meg a címszóválogatást." (LUKÁcs 2010: 39.)

Ezeket a lexikai elemeket gyakran a reáliák (vagy ekvivalens nélküli lexémák) körébe szoktuk sorolni, melyek nyelvi közvetítése különös nehézséget okoz, hiszen ,egyegy nyelvközösségre sajátosan jellemző jeltárgyat” jelölnek (KLAUDY 1994: 25).

A kulturális szótárak tehát sajátos kulturális töltetü, kultúrafüggő lexémákat tartalmaznak: ide tartoznak azok a nyelvi elemek, amelyekben „,kifejeződik egy adott kultúrközösség sajátos élmény- és ismeretanyaga, tárgyai, fogalmai, mentális, emotív sémái, amelyek az adott kulturális kontextusban speciális jelentéssel bírnak" (VALLÓ 2000: 45).

Ez indokolja, hogy a kulturális szótárakban a címszavakat nem pusztán azok nyelvi megfelelöje követi, hanem tulajdonképpen egyfajta értelmezés: „A kulturális szótárban tehát nem a címszavak forditását olvashatjuk, hanem magyarázatát - ahol is a magyar magyar-áz szó, az etimológia felől nézve, különösen találó: kifejtjük magyarul, mit jelent nagyjából egy olyan idegen szó vagy név, amelynek különben nincs pontos vagy hozzávetőleges magyar szótári megfelelője.” (GYÖRFFY 2018: 6; a kiemelések az eredetit követik.)

Mivel a címszóállomány mindig a forrásnyelvi kultúra (vagy kultúrák) adottságaitól függ, valószínüleg lehetetlen objektív kritériumokat találni a lemmaválasztáshoz; ez ráadásul nagyban függ a szótárírók (többségükben gyakorlott fordítók) megítélésétől, tapasztalataitól, egyéni ízlésétől is.

Nem teljesen egységes a nyelv és kultúra, illetve ország összefüggésének kezelése sem a különböző kulturális szótárakban. Az angol kulturális szótár (BART 2018) természetszerüleg tartalmaz brit/kelta (ír, skót) nyelvi elemeket, ugyanakkor nem terjed ki az angol nyelvű országok mindegyikére. Ez annál is inkább indokolt, mert az amerikai kulturális szótár (BART 2017) külön kötetben jelent meg, természetesen az amerikai szónak az (angol nyelvü) Amerikai Egyesült Államokra vonatkozó jelentésében, Amerika többi részét figyelmen kívül hagyva. Ugyanakkor a német kulturális szótár (GYÖRFFY 2018) az összefüggő német nyelvterület (Németország, Ausztria, Svájc) egészéről tartalmaz címszavakat, vagyis a német szó jelentése a címben: 'német nyelvü'.

A továbbiakban néhány kulturális szótár összehasonlításával igyekszem bemutatni a kulturális szórákban szereplő tulajdonnévanyagot. Az összehasonlításban szereplő szótárak: angol (BART 2018), amerikai (BART 2017), francia (ÁDÁM 2005), német (GYÖRFFY 2018), olasz (SZTANÓ 2008). 
2. A kulturális szótárak cím- és lemmaválasztásáról. A korábban megjelent (első kiadású) kulturális szótárak címében - a hagyományos szótárakhoz hasonlóan - nyelvpárok szerepelnek: angol-magyar, francia-magyar, német-magyar stb. Az újabb kiadású szótárak már csak a forrásnyelvet viselik címükben: Amerikai kulturális szótár (BART 2017), Német kulturális szótár (GYÖRFFY 2018). BART ISTVÁN idegen nyelvü sorozatában a nyelvpár alcímként jelenik meg: La Hongrie et les Hongrois. Magyarfrancia kulturális szótár (BART 2005).

BART ISTVÁN (2018) az angol-magyar szótár előszavában nem a szótár szavai, hanem a szavak által bemutatott valóságszeletek felöl közelíti meg a szótár célját: „A brit élet és életforma jellegzetes szokásait és hagyományait, a mindennapi élet és az ünnepnapok rítusait gyüjti össze ez a szótár, továbbá bemutatja az ezekhez tartozó tárgyakat, vagyis a brit életforma kellékeit” (BART 2018: 7). A szerző hangsúlyozza, hogy szótárában elsősorban olyan szavakat mutat be, amelyek jelentése (és valószínüleg konnotációja) a kétnyelvü szótárakból nem ismerhető meg. Az előszóból nem derül ki, hogy a tulajdonnevek milyen szerepet játszanak a szótárban.

Hasonló elvek alapján válogatta be a címszavakat az amerikai kulturális szótárába is, a válogatásban a szavak mögöttes jelentése és hangulata játszotta a legfontosabb szerepet. „Nos, mi [...] föként olyan egyszerü fogalmakat, tényeket és tárgyakat - szavakat! - szerepeltetünk (és próbálunk megvilágítani) ebben a szótárban, melyek az amerikai életformát - történelmet és hétköznapokat - tükrözik, jellegzetes amerikai értékek és hagyományok jelennek meg bennük, és ekképpen részét, mondhatni kötőanyagát alkotják az amerikai kultúrának" (BART 2017: 6). A tulajdonnevek szerepéről itt sem esik szó.

ÁDÁM PÉTER francia kulturális szótárát az előszóban „Land und Leute típusú kislexikonnak” nevezi (ÁDÁM 2005: 5). A szócikkek témáinak felsorolása: „évszám, sanzoncím, történelmi évforduló, népszokás, borelnevezés, híres csata, rejtett irodalmi idézet, nagy történelmi személyiség, közhely, szállóige" stb. (ÁDÁM 2005: 5) utal arra, hogy a szótár szócikkei között több tulajdonnevet is találunk.

GYÖRFFY MIKLÓS német kulturális szótára előszavában ugyancsak a „kulturális felhangú" szavakat jelöli meg szótára tartalmaként. Ezen olyan lexikai elemeket ért, amelyeknek ,vannak ugyan szótári megfelelöi(k), [...] mégis tartalmaznak lefordíthatatlan jelentésárnyalatot vagy jelentéstöbbletet” (GYÖRFFY 2018: 6). A szerző a lemmaválogatás bemutatásakor részletesen kitér a tulajdonnevek szerepére. Miután megjegyzi, hogy a „tulajdonnevek egy részének jelentős és persze eleve lefordíthatatlan kulturális konnotációja van" (GYÖRFFY 2018: 7), bemutatja a feldolgozott tulajdonnevek kiválasztásának módszerét. „Személyneveket és földrajzi neveket csak akkor szerepeltetek címszóként, ha azok valamilyen körülhatárolható értelemben fogalommá, esetleg köznévvé váltak. Kivételt csupán a történelmi és földrajzi tartományok, régiók, tájegységek nevével, valamint néhány német nagyváros [...] nevezetességeinek, helyszíneinek elnevezésével tettem [...].” (GYÖRFFY 2018: 7.) Ezenkívül megtalálhatók a szótárban olyan, tulajdonnevekből keletkezett „kulturális címszavak és fogalmak”, amelyek a német, osztrák és svájci történelemmel, müvészettel, tudománnyal stb. kapcsolatosak, és nincs célnyelvi megfelelöjük (GYÖRFFY 2018: 7).

Az olasz-magyar kulturális szótár előszavában a szerző a müfajt így határozza meg: „A kulturális szótár először is szótár” (SzTANÓ 2008: 6). Szócikkei nagyjából egy útikalauz anyagát ölelik fel, csak nem földrajzi, hanem betürendes elrendezésben. Az elöszó alapján a lemmák között kevés tulajdonnevet várhatunk: „Személyneveket nemigen vettünk fel, hacsak nem váltak fogalommá” (SZTANÓ 2008: 6). Hasonlóan jár el a szerző 
a hely- és intézménynevekkel. A szerző több esetben a tulajdonnévi címszavaknál (is) utal a címszóhoz hasonló funkciójú magyar (vagy más: francia, amerikai) tulajdonnevekre, egyfajta ekvivalenciaként: pl. a Cuore címü ifjúsági regény szócikkében: „az olaszok Pál utcai fiúkja" (SZTANó 2008: 90).

Egyedül az olasz-magyar kulturális szótárban van névmutató (SZTANÓ 2008: 302304), amely szándéka szerint nem a címszavakat tartalmazza, hanem a szócikkekben szereplö tulajdonneveket.

A tulajdonnevek aránya a kulturális szótárakban a fentieknek megfelelően változó. Az $A$-nál szereplő címszavakat részletesen áttekintve és átszámolva az alábbi eredményeket kaptuk. A számolásnál csak a pusztán tulajdonnévi címszavakat, illetve a teljes szócikkeket vettük figyelembe, azokat a címszavakat tehát nem, amelyek után csak egy utalás található, pl. Academy $\rightarrow$ Royal Academy of Arts (BART 2018: 10). Nem számoltuk kétszer, ha ugyanazt a fogalmat jelölö nyelvi forma két alakban is szerepelt a címszavak között: ABA, illetve American Bar Association (BART 2017: 7).

1. táblázat: Tulajdonnevek aránya az $A$ alatti címszavak között ${ }^{2}$

\begin{tabular}{|l|c|c|c|}
\hline Szótár nyelve & $\begin{array}{c}\text { Szócikkek } \\
\text { száma (db) }\end{array}$ & $\begin{array}{c}\text { Tulajdonnevek } \\
\text { száma (db) }\end{array}$ & $\begin{array}{c}\text { Tulajdonnevek } \\
\text { aránya (\%) }\end{array}$ \\
\hline angol & 108 & 42 & 38,9 \\
\hline amerikai & 128 & 63 & 49,2 \\
\hline francia & 111 & 35 & 31,5 \\
\hline német & 62 & 42 & 67,7 \\
\hline olasz & 98 & 34 & 34,7 \\
\hline
\end{tabular}

A táblázatból láthatjuk, hogy a tulajdonnevek aránya a szócikkek 1/3-a és $2 / 3$-a között mozog; a német szótárban találjuk arányosan a legtöbb tulajdonnévi címszót. Összehasonlításképpen: a szigorúan korpuszalapú, elexico nevü német online szótárban a címszavak 1,2\%-a tulajdonnév: 3689 tulajdonnév szerepel a 300000 címszó között. Ezek legnagyobb része családnév (1334) és helységnév (1065), a többi pedig tájnév (332), utónév (267) és országnév (189) (KLOSA et al 2010: 658). ${ }^{3}$

\section{Földrajzi nevek a kulturális szótárakban}

3.1. Angol kulturális szótár. Az angol kulturális szótár bővelkedik különböző típusú földrajzi nevekben. Ezek sorában természetesen előfordulnak vízrajzi nevek. A Severn folyónév szócikkében elsősorban földrajzi ismeretek olvashatók: ,a sziget leghosszabb $(290 \mathrm{~km})$ folyója, amely Északkelet-Walesben ered, és a Bristol Channelbe ömlik; ha bore (tidal wave) van rajta, utolsó szakaszán a dagálytól visszafelé folyik a vize." Az Avon folyónév mellett olvashatjuk: „több angliai folyócska neve, melyek közül Shakespeare [...] okán a Stratford városán átfolyó a legismertebb.”

${ }^{2}$ A számlálás a 2. pontban számba vett, a tanulmányban feldolgozott kiadások alapján történt.

${ }^{3}$ Az elexico az Institut für Deutsche Sprache projektjének keretében készült online szótár, a jelenkori német köznyelv szóanyagát tartalmazza: https://www1.ids-mannheim.de/lexik/elexiko.html. (2020. 05. 02.) 
A hegyneveknek a forrásnyelvben használatos formája mellett nem feltétlenül található meg a magyar megfelelője: a Pennines leírása szerint „a skót határtól [...] Derbyshire-ig, 400 km hosszan dél felé húzódó hegység”. A szócikkből hiányzik a magyar megfelelö (Pennine-hegység).

Az Albion címszónál a következő etimológiai, stilisztikai megjegyzéseket olvashatjuk: „Nagy-Britannia régi (talán kelta eredetü), ma már leírhatatlanul poétikus neve.” Az Ireland országnév több, egymással utalásokkal összekapcsolt változatban is előfordul a szótárban. Közülük a leghosszabb szócikk, az Ireland tulajdonképpen a rendkívül terhelt angol-ír viszony történetét és mai állapotát foglalja össze dióhéjban: ,a hate-love viszony Írország és Anglia között kölcsönös.” A rokon szócikk, az Eire objektív földrajzi és történelmi adatokat közöl az Ír Köztársaságról, míg az Erin nyelvi információkat ad meg: „Írország költői neve, ír nyelven.”

A településnevek közül a másodlagos jelentéssel (is) bírók kaptak helyet a szótárban: a John o'Groats földrajzi névként egy északkelet-skóciai kis helységet jelöl (,,a szigetek legészakibb települése"), másodlagos jelentése azonban egy állandósult szókapcsolatból derül ki: „from Land's End to John o'Groats” ('az ország egyik végétől a másikig'). A szótárban természetesen a Land's End is kapott külön szócikket.

Városrészek is szerepelnek a szótárban szócikkel: a Mayfair a városrész neve a felső tízezer (upper class) beszédmodorával fonódott egybe, ezért ennek a (szociolingvisztikai) összefüggésnek a magyarázata tölti ki a szócikk nagy részét. A Soho szócikk is leginkább a városnegyed történetével és funkcióváltásaival ismertet meg, kiegészítve némi etimológiai magyarázattal: „a so-ho eredetileg vadászkiáltás volt, ugyanis valamikor királyi vadaskert terült el ezen a környéken.’"

A szótárban számos, jelentős konnotációval bíró mikrotoponima is található. Falls Road: „Belfast katolikus részének főutcája, mely robbantásokról, merényletekről és az itt lezajlott összecsapásokról lett nevezetes." A The Mall (lemmaként: Mall, The) utcanév szócikke a hely földrajzi elhelyezkedéséröl, növényzetéről, egykori és mai funkcióiról tudósít, miközben számos további földrajzi (és egyéb) névhez utalja tovább az olvasót (Buckingham Palace, Trafalgar Square, illetve Royal Society).

Fiktív földrajzi nevek is felbukkannak a szótárban: Ambridge képzeletbeli angol falu, a The Archers címü végeérhetetlen rádiójáték-sorozat (afféle Szabó család) helyszíne.

A szótárban a névanyagban gyakran elöforduló földrajzinév-elemeket is találunk: az ír Kil „helynevek jellegzetes előtagja, jelentése 'egyház' ('templom’), pl. Kilkenny”.

3.2. Amerikai kulturális szótár. Az amerikai kulturális szótárban a földrajzi nevek számos fajtája előfordul. A víznevek között például: Great Lakes. A szócikk a tavak rövid földrajzi bemutatásával kezdődik: „öt hatalmas, édesvizü tó láncolata az USA és Canada határán (nagyság szerint: Superior, Huron, Michigan, Erie, Ontario)", majd a tórendszernek a gazdaságban betöltött szerepét ismerteti. A szócikk a tulajdonnév magyar megfelelöjét (Nagy tavak) nem tartalmazza.

A folyónevek közül álljon itt példaként a Mississippi River, amelynek szócikke az előzőhöz hasonlóan épül fel: földrajzi bemutatást tartalmaz (,az USA legnagyobb folyója a Missouri és az Ohio összefolyásából"), és a régió életében betöltött szerepét hangsúlyozza. A szócikk továbbirányítja az olvasót az Ol'Man River tulajdonnévhez, amely „Oscar Hammerstein száma a Mississippiröl, amelynek neve indián nyelven »Nagy Víz«".

A Rocky Mountains a földrajzi információkon túl (,Alaszkától Új-Mexikóig terjedő, csaknem 5000 km hosszú hegylánc az USA nyugati részén, gerince alkotja a kontinens 
vízválasztóját”) az Aspen helységnévre utal tovább. Aspen nem méreténél fogva került a szótárba, hanem mert régen és ma is „különleges” helynek számított: „,hajdan ezüstbányászok lakták, ma a világ legelegánsabb síterepe."

A szótár számos helység- és helységrésznevet tartalmaz. A New Orleans magyarázata a település földrajzi elhelyezkedésének és legfontosabb nevezetességeinek (French Qarter és jazz) összefoglalásából áll, megadja a város nem hivatalos elnevezését is („közkeletü nevén a Big Easy”). A Georgetown szócikkben a „Washington legelőkelőbb elövárosa" megjelölés mellett a hely mai megjelenésének a bemutatása alkotja a magyarázat nagy részét. A terjedelmesebb a Harlem szócikk, amelyet a szótárban megelőz a Harlem Globetrotters és a Harlem Renaissance, a városrész nevéhez füződő szegénység és etnikai problémák bemutatására helyezi a hangsúlyt, illetve röviden ismerteti a hely történetét, emellett megemlíti a tulajdonnév holland eredetét (Nieuw Haarlem). A nagyon rövid Manhattan szócikk csak a városrész helyét jelöli meg, nem utal tovább a Hell's Kitchen szócikkre (vö. „Manhattan közepén [...] elterülö utcák”), ahonnan azonban van utalás a Manhattan-re. A Camp David, vagyis az elnöki nyaraló neve is helyet kapott a szótárban; hajdani politikai szerepe a róla elnevezett Camp David-i egyezmény (1978) aláírásának helyszíneként nem szerepel a szótárban.

A mikrotoponimák között számos utca- és hídnevet találunk. A Central Park szócikke New York City legnagyobb közparkjának a történetéről és mai funkcióiról szolgál információkkal. A Basin Street szócikke a New Orleans-i utca és a jazz kapcsolatára helyezi a hangsúlyt.

A Golden Gate Bridge szócikkében a San Francisco-i öböl hídjának magyar nevét (fordítását) is megtaláljuk: Aranykapu; ezenkívül méreteit és építésének idejét is olvashatjuk.

Az amerikai kulturális szótárban fiktív helynevek is elöfordulnak, például a Gotham. Magyarázataként ez áll: ,,az angol 'Rátót'”, vagyis az együgyü, buta emberek lakóhelye. A fiktív helynév szócikkében angol-amerikai összevetés is található: „Amerikában elevenebben él a szó, ugyanis [...] New York zsurnalisztikus szinonimája ma is."

3.3. Francia kulturális szótár. A francia-magyar kulturális szótárban szintén találkozunk - történelmi, kulturális vagy más szempontból jelentős - földrajzi nevekkel, bár arányuk lényegesen alacsonyabbnak tünik, mint a többi hasonló kulturális szótárban.

A történelmi országnevek csoportját képviseli a Gaule : Gallia. A szerző a magyar megfelelő megadása után részletesen ismerteti a gall és francia népnevek, illetve a Gallia és Franciaország közötti bonyolult összefüggéseket, az országnév mai értelmezését. A modern országnevek közül megtaláljuk például a Martinique címszót, mely definícióval kezdődik: „A sziget 1635-től francia gyarmat, sokáig a cukornádtermesztés egyik központja." Hajdani francia fennhatósága okán a Canada is címszóként szerepel a szótárban: ,,az ott élő franciák és az ott beszélt (erősen archaikus) francia nyelv miatt változatlanul része a franciák tágabb horizontjának."

A tájnevek közül megtaláljuk a szótárban az Alsace-t: „Talán az egyetlen igazi région.” A szócikk tömören, mégis sok szempontot figyelembe véve tudósít a Franciaország többi részétől nagyon eltérő tájegység történetéről, vallási és főként (bonyolult) nyelvi helyzetéröl. A Camargue is szerepel a szócikkek között, meghatározásaként ezt olvashatjuk: „Sós taváról (Vaccarès), különleges madár- és növényvilágáról, valamint szilaj ló- és bivalytenyésztésről ismert, kb. 85 ezer hektárnyi tavas-mocsaras síkság a Rhône deltájában Provence-ban.” A Jardin de (la) France szócikke definíciószerűen 
adja meg a címszó jelentését: „Franciaország virágoskertje.” Csak ezután derül ki, hogy „a franciák a Loire völgyét értik rajta”.

A szótár szerint a valós és fiktív földrajzi nevek határán található az Occitanie: „A valamikor a langue d'oc nyelven, illetve e nyelv különböző dialektusain beszélő déli országrész (fantázia)neve [...]. A szót, amelynek nincs valóságos történelmi referenciája (ilyen nevü ország vagy országrész politikai egységként sohasem létezett), ma is hallani."

Gyakori címszavak a helységnevek, pl. Domrémy (Domrémy-la-Pucelle), ahol Jeanne d'Arc született, és ahonnan országmentö útjára indult. A szócikkben a településnek a történelmi hősnő életében játszott szerepéről olvashatunk (de földrajzi elhelyezkedéséről nem). A Paris nem szerepel címszóként, a Paris intra muros (lat.) viszont igen, ez a „sajtóban gyakran használt közigazgatási kifejezés, a boulevards extérieurs által közrefogott húsz párizsi kerület együttesen".

A mikrotoponimák közül megtaláljuk a Champs-Élysées (avenue des) szócikket, amelyben a sugárút különbözö háborús helyzetekben betöltött (szimbolikus) szerepe jelenik meg hangsúlyosan.

Természetesen jelentős épületek is helyet kaptak a szótárban. A Notre Dame de Paris meghatározása szerint ,az ország harmadik legfontosabb székesegyháza”. A szótáríró ezután ismerteti azon jeles irodalmi és történelmi vonatkozásokat, amelyek a templomhoz (és nevéhez) kapcsolódnak.

3.4. Német kulturális szótár. A német kulturális szótárban a vízrajzi nevek között számos folyónevet találunk. Természetesen a legnagyobbakét: Elbe, mellette a magyar névformát: Elba, majd az Elba legfontosabb földrajzi adatait és jelentőségének bemutatását. Hasonlóan épül fel a Rhein (Rajna) szócikke, itt azonban a folyónév latin, francia és holland névformáit is megtaláljuk. A Donau (azaz 'Duna') nem szerepel címszóként.

Németország egyik tengere, a Nordsee (azaz 'Északi-tenger') nem található meg címszóként a szótárban, az Ostsee viszont igen, talán azért is, mert két magyar megfelelője van: „Keleti- v. Balti-tenger”. A Neusiedler See címszónál megfeleltetést lehet olvasni: „A Fertő tó német neve.”

A német nyelvterület hegynevei közül szerepelnek az egyes országok legmagasabb csúcsai. Großglockner: ,,az osztrák Alpok legmagasabb hegycsúcsa: 3798 m magas.” Hasonlóan épül fel a Zugspitze szócikke is: „Németország legmagasabb hegycsúcsa (2963 m) az Alpokban." Történelmi vagy irodalomtörténeti szempontból jelentős hegységek, csúcsok, sziklák neveit is ismerteti a szótár. A Loreley egy „132 m magas sziklaorom a Rajna-mentén Mainz és Koblenz között”, amelyet Heinrich Heine tett halhatatlanná.

A szótár számos tájnevet sorakoztat fel. Már a tájnevek áttekintéséből kiviláglik, hogy a szótár a címében szereplő német alatt a német nyelvü országokat, illetve az egykori német nyelvü közép-európai területet érti. Ezek között vannak a mai német nyelvű országok területén találhatók, pl. Breisgau (D), Graubünden (CH), Lausitz (D), Mühlviertel (A). A Breisgau szócikk földrajzi meghatározást (,,délnémet tájegység, amely a Rajna felső folyása és a Schwarzwald között található") és rövid történelmi bemutatást tartalmaz, majd ismerteti a forrásnyelvi nyelvhasználók számára evidens $i . B r$. (= im Breisgau) rövidítést. A Mühlviertel szócikke hasonlóan épül fel: a rövid földrajzi definíciót (,,300-1300 m magas felső-ausztriai középhegység a Dunától északra; a Cseh-erdő déli nyúlványa") a név jelentésének megadása ('malomnegyed'), majd ennek magyarázata követi. Egyes tájnevek köznévi jelentésük miatt kerültek be a szótárba: pl. az Emmenthal, amelynek jelentése után ('az Emme folyó völgye') megtudhatjuk, hogy „,[i]tt, illetve itteni eljárás 
szerint készül az ementáli sajt"; a köznév immár illeszkedett a magyar helyesíráshoz. Az Elsass szócikkben megtaláljuk a magyar megfelelőt is (Elzász).

A településnevek között nagy számban fordulnak elő az egykor német nyelvü területek városai. Pl. Hirschberg (a lengyelországi Jelenia Góra): a sziléziai város ,egykori” német neve. Marienbad, a mai csehországi Mariánské Lázně német neve mellett a fürdővárosnak a német kultúrtörténetben betöltött szerepét ismerjük meg, különös tekintettel a híres fürdővendégekre: Wagnerre, Lisztre és Goethére. Breslau: Wrocław, a szócikk ismerteti a lengyelországi város lassan feledésbe merült magyar történelmi nevét is (Boroszló). A fenti településnevekhez csatlakoznak a korábban Magyarország részét képező német városok névpárjai, pl. „Bartfeld Bártfa (ma Bardejov, Szlovákia) német neve”, Neusohl (Besztercebánya, Banská Bystrica)". Hasonlóan önálló címszóként szerepel a Hermannstadt (Nagyszeben, ma Sibiu/Románia) stb. Ezekben az esetekben tehát a mai hivatalos nyelvi névalak mellett a korábban használatos német és magyar megfelelöket is megtaláljuk, amelyek névpárokat alkotnak, illetve párhuzamos nevekként jelennek meg a szótárban.

Mai magyarországi városoknak gyakran van (volt) német elnevezése is, ezeket is nagy számban tartalmazza a szótár: Fünfkirchen (Pécs), Güns (Köszeg), Raab (Györ), Ödenburg (Sopron), Ofen (Buda). Ezekben a szócikkekben a német név etimológiáját, illetve kialakulásának motivációját is megadja a szerző.

A mikrotoponimák közül sok városrész és utca nevét megtaláljuk a szótárban: általában azokat, amelyeket valamilyen esemény, látványosság, intézmény vagy irodalmi mü tett ismertté. Az egyik bécsi külváros neve, a Grinzing a borozóiról, a másiké, a Döbling pedig (nekünk) Széchenyi István miatt nevezetes. Az épületnevek szintén a teljes német nyelvterületet reprezentálják. Ezek a szócikkek az épületnevek „fordításával” kezdődnek, majd azt követi az épület rövid bemutatása (magyarázata), pl. Brandenburger Tor: „Brandenburgi kapu”, Kapuzinergruft: „kapucinus kripta”.

A címszavak között homonim német nevek is előfordulnak, amelyeknek egy szócikkben találjuk meg különböző megfelelőit. Ilyen a Marburg: „,a Lahn folyó mellett (an der Lahn) fekvő, ma is így nevezett egyetemi város mellett ez (volt) a szlovéniai Maribor német neve is (an der Drau, azaz 'a Dráva mellett' jelzői értékủ határozóval). Interlingvális homonimákra, pontosabban egy homográf névpárra külön utalást olvashatunk. Eger: „,a magyar város nevével írásban tökéletesen megegyező, csak kiejtésében ('éger') eltérő német városnév", a mai csehországi Cheb német megnevezése.

3.5. Olasz kulturális szótár. Bár vízrajzi és hegyneveket hiába keresünk az olasz kulturális szótárban, a szótár az egyéb földrajzi nevek különböző típusait tartalmazza.

Az országnevek közül - Olaszország ,érdekeltsége” okán-megtalálható az Abissinia: „Abesszínia, más néven Etiópia, az olasz gyarmatosítási törekvések egyik fő célpontja.”

A tájnevek között különösen fontos az észak-olaszországi régió, Alto Adige neve, amelynek megfelelője nem magyar, hanem német („németül Südtirol”), bár a szócikk szövegében előfordul a dél-tiroli melléknév is. A jelentős konnotációval bíró tulajdonnevek közé tartozik a Trinacria: „Szicília antik neve, ma a sziget önazonosságának és függetlenségének egyik kifejezője, érzelmi töltése kb. olyan, mint nálunk a 'Hungária', 'Magyar hon', 'Szittyaföld' szavaknak." A történelmi áttekintés mellett megismerhetjük a szó eredetét is: a görög trinakrios ('három hegyfok') átvétele.

Több városnév szerepel a szótárban: Bari, Fiume, Trieste. A városnevek szócikkei az adott város közigazgatási szerepét, földrajzi bemutatását és rövid történetét tartalmazzák. Pl. Bari: „Puglia tartomány székhelye.” A Fiume szócikkből hiányzik a ma horvátországi 
város hivatalos nyelvi megnevezése (Rijeka), így a névpár tagjainak azonos jelentéséről ('folyó') sem esik szó, annál inkább a város mozgalmas történetéről. Trieste szócikke szintén nem tartalmazza a többnyelvü és -nemzetiségü város többi nevét: horvátul és szlovénül Trst, németül Triest, magyarul Trieszt. Ehelyett a helység földrajzi helyének leírása olvasható: ,a Szlovéniába beékelődő olasz földnyelven fekvő város.”

Az itáliai városok közül jó néhánynak van - az olaszok számára közismert - ragadványneve; a szótár ezeket is számba veszi. Città del Santo (Padova, 'szent [Antal] városa', Bologna la Grassa ('kövér'), Dotta ('tanult, tudós', Bologna, illetve Padova), Superba („Genova állandó jelzője”). Az Urbe városnév Róma latin nevéből, az Urbs-ból származik, ,az $\sim$ n kizárólag Róma értendő”.

A földrajzi nevek címszavai között vannak fiktív nevek is, pl. Cuccagna: „Dínomdánom ország, Eldorádó". A név a középlatin cocaniá-ból alakult ki, amely pedig a német Kuchen ('sütemény, édesség') szóra vezethető vissza. A Cuccagna szinonimája a Bengodi, jelentésében nem, csak használatának gyakoriságában különbözik az előzőtől.

\section{Személynevek a kulturális szótárakban}

4.1. Angol kulturális szótár. Az angol kulturális szótárban természetesen számos személynév is található a történelem és a müvészetek, különösen az irodalom területéröl.

Az Arthur, King szócikk a brit nemzeti történelem egyik legismertebb szereplöjét mutatja be néhány mondatban, némiképp homályban hagyva, hogy valós történelmi alaknak tartja-e: ,az alak történelmi előképe alkalmasint brit (kelta) király lehetett, aki az angolszász hódítók ellen küzdött az V. században.” Az Albert, Prince szócikk a névviselő családjáról („Viktória királynő férje, a Saxe-Coburg and Gotha német hercegi család sarja”) és az angol kultúrában betöltött szerepéről tudósít („olyan nagy befolyása volt a királynőre, hogy általa tkp. az ő szellemisége formálta az egész Victorian kort").

A valós személyek neve mellett számos fiktív, mesebeli vagy irodalmi alak nevét is tartalmazza a szótár. John Bull a „tipikus angol” szatirikus figurája, a fiktív személynév mellett az alak kialakulásának története és a hozzá füződő képzetek olvashatók. A szótáríró a tárgyalt nevet magyar személynévnek is megfelelteti („,kb. Bika Berci”).

Klasszikus mesealakok angol neve (megfelelöje) is megtalálható a szótárban: Little Red Ridinghood a mesebeli Piroska. A nagyon régi és rendkívül sok változatban élő történetet a szótáríró Charles Perrault-hoz köti, és legjellemzőbb mondatait, a kislánynak a nagymamához intézett kérdését és a farkas válaszát idézetként, forrásnyelvi alakban közli. Travers mesealakjának neve, a Mary Poppins még címszó volt a szótár korábbi kiadásában, a felújított kiadásban azonban már nem szerepel. A szintén fiktív Dr Dolittle személynév szócikke a gyermekkönyvek doktor bácsiját mutatja be néhány sorban, itt a névkiegészítö is a címszó része.

Agatha Christie regényeinek detektív hősei is szócikket kaptak az angol kulturális szótárban: Miss Marple éppúgy, mint Hercule Poirot: nevük a krimikből ismert alakban szerepel címszóként, rövid bemutatásuk regénybeli viselkedésükre korlátozódik. Különös névtani helyzetet mutat be a Laurel and Hardy szócikk, amelynek címszavában az angol nézők számára az ismert színészek (Stan Laurel és Oliver Hardy) családneve, magyar megfelelöként pedig ugyanezen (szintén jól ismert) személyek magyarban ismert neve áll: Stan és Pan.

A szótár gyakori családnévelemeket is tartalmaz szócikként: a Mac skót és ír családnevek elötagja (,jelentése: son of'), az $O$ ' ír patronimikumok előtagjaként 'unoká'-t, 'leszármazott'-at jelent, a Gil jelentése 'valakinek a fia'. 
A szótárban ugyancsak megtalálható az erős konnotációjú Kevin. A jellegzetesen ír utónév a Kenneth-nek a változata, az „,angolokban durva és erőszakos modorú, iskolázatlan fiatalember képét idézi fel".

4.2. Amerikai kulturális szótár. A szótárban számos valódi személynév található; a híres névviselők között sok a politikus, katona, sportoló, színész.

Van ugyan Lincoln, Abraham címszó, mögötte azonban nem áll szócikk, csak utalások sora, többek között az Honest Abe szócikkre, melyben a következő definíció olvasható: „Lincoln elnök szeretetteljes beceneve, amely egész jogi és politikai pályáján elkísérte." A politikusok nevei közül elsősorban az amerikai elnököké bukkan fel a szótárban. Pl. George Washington: ,az Egyesült Államok első elnöke virginiai földbirtokos volt." Andrew Jackson hivatalos neve mellett ragadványneve is szerepel („Old Hickory”: 'elnyühetetlen'), Thomas Jefferson: ,,az Egyesült Államok harmadik elnöke.” A politikában jelentős személyek nevei között találjuk a Hoover J., Edgar-t, az FBI megteremtőjének nevét; a bemutatásban a közéletben betöltött funkcióit és legfontosabb tulajdonságait egyaránt megismerjük. A Harriet Tubman szócikkből megtudjuk, hogy a név viselője rabszolgának született, mielőtt politikai pályára állt; az ő ragadványneve csak magyar alakban olvasható: „fekete Mózes”.

A személynevek között több sportoló nevét is megtaláljuk: Yogi Berra a New York Yankees híres baseball játékosa, Jack Dempsey „legendás hírü amerikai ökölvívó” az 1920-as években. A sportolók személynevei után álló rövid bemutatások ugyanazon minta alapján épülnek fel.

Az amerikai kultúrát indián személynevek is reprezentálják: Crazy Horse ,az Oglala $\rightarrow$ Sioux törzs fönöke”, Hiawatha „legendás indián törzsfö, az Iroquois League megalapítója”.

A híres személyiségek neve a családnévvel kezdődően szerepel a szótár betürendjében, például a Presley, Elvis szócikk esetében is. A személynév melletti magyarázat: ,a rock'n'roll első nagy sztárja." Az amerikai müvészetet különböző müvészeti ágakban tevékenykedő hírességek reprezentálják. Houdini Harry híres „szabadulóművész”, a szócikkben fény derül magyar származására (eredeti neve: Weisz Erik).

A szótárban természetesen fiktív nevek is előfordulnak, közülük sokan híressé vált filmek szereplöi, pl. Tarzan. A Batman címszó után magyar megfeleltetés is olvasható: „a Denevérember, [...] az alvilág réme, polgári nevén Bruce Wayne.” Innen utalás irányít a Spider Man szócikkhez (ott azonban Spiderman alakban szerepel), onnan további utalás található a Superman szócikkhez, így füzve össze a csodálatos képességű figurákat.

4.3. Francia kulturális szótár. Különböző típusú személynevekkel találkozunk a francia kulturális szótárban: szentek nevétől mai politikusok nevéig. A szentnevek a valós személynevek közé sorolandók. A francia kulturális szótárban nyilvánvalóan más „releváns” szenteket találunk, mint akikkel a magyar egyház- és kultúrtörténetben szoktunk találkozni. A 3. században élt hittérítő, Saint-Denis neve mellett vértanúságának története, ünnepnapja és ikonográfiai hagyományai olvashatók. A szócikk a magyar megfelelővel kezdődik: Szent Dénes. A magyar megfelelő (Szent Ottília) nélkül áll a Sainte-Odile címszó, Elzász védőszentjének neve.

Felvett egyházi név az abbé Pierre, amely mellett szintén megadja a szótár a magyar megfelelőt: Péter apát, majd a névviselő polgári nevét is: Henri Grouès. „A szókimondó kapucinus neve, amelyet egész Franciaország ismer, a szegényekkel és hajléktalanokkal való önzetlen törödés és együttérzés szinonímája [sic!].” 
A személynevek közé sorolhatjuk a szótár Roland címszavát is: „Ha fiktív személy, ha nem, az első nemzeti hős." A szócikk nagy részét a vele kapcsolatos történelmi eseményről szóló francia nyelvü idézet és annak magyar fordítása teszi ki.

A történelmi kollektív neveket képviseli a Carolingiens és a Mérovingiens, mindkét címszó magyar megfelelőjét is megtaláljuk (Karolingok, illetve Merovingok). Ugyancsak mindkét szócikkben van utalás a név eredetére (etimológiájára), majd a szerző ismerteti az uralkodócsaládnak a francia történelemben betöltött szerepét. Az utóbbi szócikkben annak magyarázatát is megtaláljuk, hogy miért lett a Louis, egészen XVIII. Lajosig, ,a francia uralkodók hagyományos keresztneve".

Meglehetősen hosszú szócikket kapott de Gaulle, illetve teljes nevén Charles de Gaulle ,[k]atona és államférfi, a XX. század egyik legnagyobb politikusa, karizmatikus történelmi személyiség". Az 1970-ben elhunyt államférfi életútját jelen időben mutatja be a szótár szerzője, ezzel is felerősítve a politikus máig tartó, élő hatását. A szócikket 13 további szócikkre történő utalás zárja.

A modern kor nagy személyiségei közül megtaláljuk többek között a Bocuse, Paul címszót, neve mellett felsorolást alkotnak a meghatározások: „Az egyik leghíresebb francia séf, a klasszikus francia konyhamüvészet hagyományának képviselője és megújítója, a francia becsületrend kitüntetettje és [...] az ,„évszázad szakácsa«.”

A Platini, Michel címszót interkulturális metaforával magyarázza a szótáríró: „A francia Puskás Öcsi.” A név jelentésének leírásában más híres labdarúgók is szerepet kapnak: „Méltó francia megfelelője Zamorának, Pelènek és Maradonának. Minden idők egyik legnagyobb labdarúgója.” Hasonló metaforára (modifikációra) a fiktív nevek bemutatásánál is találunk példát: Toto „a francia viccek Mórickája”.

A fiktív élőlények nevei közül bekerült a szótárba a mesebeli Tarasque neve: „A legenda szerint Tarascon környékén élö tüzokádó sárkányforma kétéltü szörny.” A szörnyhöz kapcsolódó mai hagyományok bemutatása egészíti ki a név bemutatását.

4.4. Német kulturális szótár. A német kulturális szótár számos személynevet tartalmaz. Közöttük elöfordulnak jelentős személyiségek nevei a legkülönbözőbb történelmi korokból, ezeket (néhány kivételtől eltekintve) definíciószerü meghatározás követi. Pl. Arminius v. Armin der Cherusker: „egy nyugati germán néptörzs, a keruszkok vezére volt.” Barbarossa: „Rőtszakállú [...] I. Frigyes (Friedrich von Hohenstaufen) középkori német-római császár olasz előneve.” Eckermann, Johann Peter: „1823-tól gazdája haláláig Goethe hüséges »famulusa«, segítőtársa, beszélgetőpartnere volt."

A szótárban külön szócikket kapott a Karl germán eredetü utónév, itt nem egy bizonyos névviselöre utalva. A szócikk a név jelentésén túl ('legény, fiú, fickó') utal a név európai elterjedtségére és az európai uralkodóházak névadásában betöltött szerepére, illetve a földrajzinév-adásban megmutatkozó jelentőségére.

A személynevek egy része több névviselőre utal. A (Brüder) Grimm címszó a G betűhöz lett besorolva, jelentése: 'Grimm-testvérek' (a két Grimm fivér utóneve nem szerepel a szócikkben.) A Fugger családnév szócikkében a családtagok közül Jakob Fugger szerepel utónévvel is. A szócikk megemlíti a családnévből kialakult Fuggerei tulajdonnevet is („lakótelep a szegényeknek”), de a családnévböl alakult magyar közszót (fukar) nem.

Az uralkodócsaládok nevei közül megtaláljuk a szótárban a Habsburger családnevet, melynek magyar megfelelője („Habsburgok”) után rövid bemutatást olvashatunk: „európai uralkodócsalád, amely a svájci Aargauban található Habsburgról kapta a nevét." 
Ugyancsak a történeti nevek csoportjába tartozik a (Kaspar) Hauser, a névviselő a leghíresebb németföldi farkasgyerek (a szótárban „lelencgyerek”) volt a 19. század első felében. A szócikk megemlíti a személynévből kialakult pszichológiai terminust (KasparHauser-komplexus) és a névviselő regényes történetének müvészi feldolgozásait.

A szótár fiktív nevekben is bővelkedik: megtalálhatók benne a Grimm testvérek mesegyüjteményének alakjai: (Frau) Holle a magyar megfelelöjével (Holle anyó) szerepel; a Hänsel und Gretel szócikkéből megtudjuk, hogy a Jancsi a Hänsel becenévi megfelelője, a Juliska mellett viszont „,az alliteráció is szólhatott”, az ugyanis nem a Gretel (Margarete) fordítása. További irodalmi (mitológiai) nevek a szótárból: Kriemhild és Siegfried, Nibelungen; ez utóbbinál (behelyettesítve) a magyar megfelelő: „Nibelungok”.

A szótár meghatározása szerint egyfajta átmenetet képez a személy- és a tárgynevek között az Ötzi: ,'Ötz-völgyi lelet', [...] egy újkőkori vadász fagyban konzerválódott teteme, azaz gleccsermúmiája." A néhai vadászt megtalálásának helyéröl nevezték el (becézőképzővel).

4.5. Olasz kulturális szótár. Az olasz kulturális szótár személynevei között találunk történelmi neveket, pl. Regina Margherita: ,az első olasz királyné, I. Umberto felesége.” A szócikk természetesen említi a személynév és a pizzafajta (pizza margherita) közötti kapcsolatot, és a királynő nevéből képzett más (földrajzi) neveket is. Címszóként szerepel a kalandos életü Anita Garibaldi neve is: ,a Risorgimento hősének [...] a felesége.”

Számos egyházi személy nevét is megtaláljuk a szótárban. Padre Pio (,,az egyik legnépszerübb szent Olaszországban") kapucinus szerzetes élete és vallási tevékenysége hosszú szócikket kapott. Civil nevén Francesco Forgione, ,szerzetesi nevén Pio da Pietralcina"; ennek utónévi tagja az egyházi megszólításával (Padre) forrt össze. Természetesen pápák nevei is bekerültek a szótárba. Papa Sisto „a római nép körében rendkívül népszerü V. Sixtus", a Papa Buono XXIII. János ragadványneve; az előbbinek a szócikkből kiderül az eredeti civil neve, az utóbbinak nem.

Nem minden személynév mellett áll a leginkább magától értetődő információ. A Verdi szócikk ,a híres zeneszerző” politikai tevékenységét és szimpátiáit tárgyalja: ,a Risorgimento szimpatizánsa volt."

A nem valós személynevek csoportjába tartozik a Pierino, ,az olasz viccek Pistikéje", a magyar kulturális szótárban - a szótáríró utalása szerint - Móricka (lenne) a megfelelője.

Ugyancsak fiktív név a Signor Rossi: ,az átlagos kisember átlagos neve.” A Signor Bianchi („Kovács úr, azaz a tökéletesen átlagos ember”) szócikkben kis névtani esszét olvashatunk a gyakoribb itáliai családnevekről. Ezek szerint az átlagos nápolyit Espositónak hívják, az északi átlagembert inkább Fumagalli-nak. A Brambilla szócikk („,Lombardiában rendkívül elterjedt vezetéknév") hasonlóan mutatja be a név gyakoriságát.

\section{Egyéb névfajták a kulturális szótárakban}

5.1. Angol kulturális szótár. A további névfajták közül szinte mindegyiknek van képviselöje a kulturális szótárban: híres épületek nevei, intézménynevek, tárgynevek, üzlet- és márkanevek, fajtanevek, címek, eseménynevek stb.

Az Ark Royal eredetileg a ,spanyol armadát legyőző (1588) angol flotta zászlóshajójának a neve volt", később több anyahajót is így neveztek el. A szótár nem füz jelentéstani vagy etimológiai magyarázatot a névhez. 
A Big Ben a londoni parlament északi tornyának óráját, illetve harangját jelöli; itt is a névhez kapcsolódó hagyományokat ismerhetjük meg, a névelemek jelentését vagy eredetét nem.

Valószínüleg az intézménynevek alkotják az egyéb nevek legnépesebb csoportját: ezek mindegyike hordoz valamiféle jelentéstöbbletet, illetve reáliák a szónak abban az értelmében, hogy nincs célnyelvi megfelelöjük. Megtaláljuk az intézménynevek között iskolák, oktatási intézmények elnevezését, pl. Oxford University. A tulajdonnév magyarázataként az egyetem történetét, hajdani és jelenlegi jellegzetes oktatási és szociális rendszerét ismerhetjük meg. A The Garrick szócikk a londoni színházi és irodalmi világ híres (kizárólag férfiak előtt nyitva álló) klubjának nevét értelmezi, megadva a név eredetét: Garrick híres 18. századi színész volt.

Az intézménynevek közé sorolandók az egyházak nevei, pl. Congregational Church, amely a nagy-britanniai református egyház elnevezése. Itt a szótáríró megadja az egyháznak, illetve híveinek forrás- és célnyelvi szinonim elnevezéseit is (puritánok, Independent, kongregacionalisták, Pilgrim Fathers). Ugyancsak intézménynév a Football Association; az angol futballvilág legfontosabb szervezetének a neve mellett a közkeletü rövidítése is megjelenik (FA). A szócikk további tulajdonnevekre is tartalmaz utalást: Football League, Premier League. Az intézmények, szervezetek között természetesen helyet kaptak a legfontosabb politikai pártok elnevezései is: Conservative Party, Labour Party, National Front. A pártok alakulási évszámán, rövid történetén kívül megismerhetjük szavazóikat, legfontosabb képviselöik névsorát, ugyanakkor a neveknek itt nincs magyar fordítása.

A szótár tulajdonnévi címszavai között számos betüszó is helyet kapott. A $D L R$ címszónál annyi derül ki, hogy az a Docklands Light Railway vasút nevének rövidítése; jelentése a Docklands címszónál válik világossá.

Számos üzlet- és márkanév is helyet kapott a szócikkek között. A Fortnum and Mason cégnévvel kapcsolatban definíciószerűen közli a szerző, hogy „minden bizonnyal a legelőkelőbb élelmiszerüzlet Londonban”. A Disprin márkanevet az adott gyógyszer használatának bemutatása követi: „a minden háznál megtalálható legközönségesebb (enyhe) fejfájás-csillapító; vízben oldva szokás bevenni.” A Jaguar márkanév (a magyar olvasók számára valószínüleg ismeretlen rövidített alakban: Jag) szintén az autómárkához kapcsolódó asszociációkat gyüjti össze („nőfogó”: crumpet catcher). A fajtanevek közül szerepel a szótárban például a Conference: „nyújtott alakú, sárgásbarna, őszi körtefajta” vagy a Granny Smith: „,nagy, zöld alma; ausztrál fajta.”

A kulturális szótárban sok cím szerepel önálló címszóként: ezek többnyire nevezetes sajtótermékek, irodalmi müvek vagy dalok (slágerek) címei. Önálló szócikket kapott a Lord's Prayer, itt a címszó után - szinte kivételesen - a magyar megfelelő áll: „Miatyánk", ezt az ima forrásnyelvi szövege követi. A közismert sajtótermékek közül megtaláljuk többek között a The Times-t. A viszonylag hosszú szócikk összefoglalja az újság hosszú és bonyolult történetét, bemutatja olvasóközönségét és jelentőségét.

Eseményneveket is felsorakoztat a szótár, például a Midsommer-t, ezt a „nyári napforduló eredeti pogány rítusait a keresztény máz alatt is megőrző germán Nap-ünnep"-et, amelynek hagyományos dátumán kívül ősi szokásait is megismerhetjük a szócikkből.

5.2. Amerikai kulturális szótár. Az egyéb nevek kategóriájában előfordul számos intézménynév, például a Guggenheim Museum és a Disneyland, amelyek személynévből keletkeztek másodlagos névadással. A Met címszó a Metropolitan Opera szócikkéhez irányít; ez utóbbi az operaház történetéről tudósít. 
A politikai pártok és mozgalmak nevei közül megtalálhatjuk a szótárban többek között a Democratic Party-t, a Republican Party-t és a Tea Party-t. Ezekben a szócikkekben a pártok rövid története, legmeghatározóbb elveik és képviselőik szerepelnek.

Természetesen számos amerikai márkanevet is felvonultat a szótár. A Cadillac $(C a d d y)$ a General Motors státuszszimbólumnak számító autójának vevőkörét mutatja be, ugyanakkor utal a névadás motivációjára is: ,a Detroit-ot megalapító és elsőül kormányzó francia Cadillac báró nevét viselő michigani városkában készül."

Eseménynevekben is bővelkedik az amerikai kulturális szótár. Az amerikai történelmet meghatározó fontos események elnevezései címszóként jelennek meg a szótárban. A Civil War megadja a név bevett déli szinonimáit (War Between the States, War of Secession), és összefoglalja a háború legfontosabb céljait és lépéseit. A történelmi eseményt jelölő címszó horderejére utal, hogy 11 további szócikkre található benne utalás. A Declaration of Independence esetében megtaláljuk a magyar tulajdonnévi megfelelőt: Függetlenségi Nyilatkozat, majd létrejöttének rövid leírását, a szócikk nagy részét azonban egy hosszabb idézet teszi ki.

Amerika újabb történetéből is találunk eseményneveket: a Nine Eleven vagy 9/11, definíciója szerint „,a New York-i World Trade Center ikertornyai ellen intézett 2001-es terrortámadás dátuma (szeptember 11.), illetve ma már magának az eseménynek a szinonimája” (tkp. inkább a neve). A szócikkből megtudjuk, hogy „a nine-eleven »odacsapni« értelemben igeként is használatos". A Great Depression (nagy világválság) szócikke - a szócikkek nagy részéhez hasonlóan - ugyancsak nem tartalmazza a tulajdonnév magyar megfelelőjét, de leírja az esemény legfontosabb lépéseit és következményeit.

A jellegzetesen amerikai ünnepek is helyet kaptak a szótár szócikkei között. A Halloween szócikke például az ünnep eredetéről, hajdani és mai szokásairól számol be részletesen: „október 31, Mindenszentek napjának előestéje.” Itt az amerikai és angol szokások egybevetésére is találunk példát.

Az amerikai kultúra európai „,kisugárzásának” jeleként a címek között számos - a filmiparral és a könnyüzenével kapcsolatos - címszót találunk. Az Easy Rider szócikke a filmcím magyar megfelelőjével (fordításával) kezdődik: Szelíd motorosok. A film egymondatos (tkp. kétnyelvü) összefoglalása mögül kiviláglik a szótáríró enyhe iróniája: „,in search of fun and freedom, amin a rock, a drug és a sex értendő.” Helyenként a címszavak magyarországi vonatkozásai is előbukkannak a szócikkekből. Pl. a Dallas esetében: „minden idők (nálunk is) legsikeresebb, máig ismételt televíziós soap operája.” A Reader's Digest folyóirat címe szintén címszó lett: itt egyfajta magyar köznyelvi meghatározást is találunk (,az olvasók zanzája”), majd az amerikai olvasói szokásokról kapunk tájékoztatást: „változatlanul a »müvelt« középosztály egyik legkedveltebb olvasmánya, és számai évekig elhevernek a nappalikban, sokan gyüjtik is."

5.3. Francia kulturális szótár. Földrajzi és személyneveken kívül számos egyéb névfajtával is találkozhatunk a szótárban.

Irodalmi és más müvek címei itt is előfordulnak. A Robert-nek nevezett szótár szócikke szerzőjének, Paul Robert-nek a nevével kezdődik: „legendás figurája a francia szótárirodalomnak.” A szótáríró életútjának rövid ismertetése után a Grand Robert egynyelvü nagyszótárt és annak rövidített, nálunk is ismert változatát, a Petit Robert-t említi a szerző. Bár a Roland személynévnél nem volt rá utalás, Chanson de Roland címszó is szerepel a szótárban; itt a szerző nem adja meg a középkori lovagi ének nevének magyar megfelelöjét (Roland-ének). 
A címek és az intézménynevek közötti átmenetnek tekinthetjük a Gault-Millau étteremkalauz nevét; definíciója: „A legjobb éttermek és vendéglők évről-évre kiadott népszerü és sürűn idézett kalauza."

Jelentős intézmények nevei is gazdagítják a szótár címszóállományát. A Louvre szócikke többszörös definícióval kezdődik: „A világ legnagyobb szépmüvészeti múzeuma, építészeti értékeinél és történelmi presztízsénél fogva az ország egyik legismertebb müemléke." Ez követi az épület építéstörténete. Hasonlóan megtaláljuk a címszavak között a Sorbonne-t; a szócikk a „nagyhírü felsőoktatási intézmény” rövid történetét mutatja be, majd röviden utal a mai francia felsőoktatásban betöltött szerepére. A franciaországi pártok neve is helyet kapott a kulturális szótárban. A Front National teljes nevével szerepel címszóként, míg a francia kommunista párt betüszóként: $P C F$, amelyet teljes neve (Parti Communiste Français) követ.

A szótár számos márkanevet tartalmaz. A Chanel $n^{\circ} 5$ esetében a címszót tömör definíció követi: „A világ leghíresebb parfümje.” A parfüm történetén túl utalást találunk híres használóira is. A Perrier név magyarázata is definíció: „Buborékos ásványvíz, a francia ásványvízpiac legismertebb terméke." Emellett természetesen megjelennek a névhez füződő asszociációk: „egy kicsit jelképe is a francia bisztrók hangulatának.” Az utalások között természetesen elsősorban a konkurens márkákat találjuk (Evian, Vittel, Volvic stb.).

A francia autómárkák nevei is címszóként szerepelnek. Míg azonban a Peugeot ,autómárka” és a Renault „francia autómárka, illetve autógyár”, addig a Citroën-t személynévi lemmaként találjuk meg (Citroën, André): „Francia nagyiparos; [...] 1919-ben létesítette autógyárát."

5.4. Német kulturális szótár. Az egyéb nevek között nagy hangsúllyal szerepelnek a szótárban politikai intézmények, szervezetek, pártok nevei. Az ausztriai és németországi pártok ismert betüszavas rövidítéseikkel találhatók meg. Némelyiknél a német nevet magyar megfelelöje követi, másoknál a szócikk szövegében később következik a magyar elnevezés. Az FPÖ: „Freiheitliche Partei Österreichs [...]. Magyarul Osztrák Szabadságpárt néven emlegetik őket.” A CDU: ,a Christlich-Demokratische Union (Kereszténydemokrata Unió) rövidítése.” A szótár az újabb szervezeteket is tartalmazza, pl. AfD: „Alternative für Deutschland (Alternatíva Németországnak); Új keletü német politikai párt, amelyet 2013-ban alapítottak."

A pártok nevein kívül történetileg jelentős szervezetek is megjelennek a szótárban: Hitlerjugend v. Hitler-Jugend; itt magyar megfelelő vagy fordítás helyett a név magyarázata olvasható: „a német nemzetiszocialista párt ifjúsági szervezete volt 1926-tól 1945-ig." Ehhez hasonlóan a német rendszerváltásban fontos szerepet játszó Gauck-Behörde neve is hosszabb magyarázatot kapott: „1990-ben létrehozott német állami hatóság." Ebben a szócikkben utalás van a Stasi mozaikszóra, amelynek szócikkében a szótáríró köznévnek tartja a szervezet nevét: „az NDK titkosszolgálatának, a Staatssicherheitsdienstnek hírhedt köznévvé vált rövidítése."

A modern élet sok más intézménye is helyet kapott a szótárban. Ezek közül sok inkább csak betüszóként ismert: $A D A C, A D N, D A A D, N D R$; ezek feloldása minden esetben megtalálható a szócikkek élén: Allgemeiner Deutscher Automobil Club, Allgemeiner Deutscher Nachrichtendienst, Deutscher Akademischer Austauschdienst (,Német Akadémiai - azaz felsőoktatási - Csereszolgálat”, ,,a Norddeutscher Rundfunk (Észak-német Rádió) rövidítése. Regionális német televízió- és rádiócsatorna”. 
Kulturális intézmények, föleg múzeumok nevével is gyakran találkozhatunk: die Albertina („,bécsi múzeum”), Albertinum („drezdai múzeum”), Kunsthistorisches $M u$ seum („Bécs híres szépmüvészeti [szó szerint: müvészettörténeti] múzeuma”). A GoetheInstitut szócikkében az intézménynév fordítása, majd magyarázó körülírása található: „Goethe Intézet; a német nyelv és kultúra külföldi ápolására és a nemzetközi kulturális együttmüködés elömozdítására."

A szótár erős történeti szemléletéből adódóan történelmi események neve is kereshetö benne, pl. Hermannsschlacht („Hermann csatája”), Nürnberger Prozess („,nürnbergi per”), Siebzehnter Juni (,Június tizenhetedike, az 1953-as szovjetellenes kelet-berlini munkásfelkelés emléknapja").

A szoros magyar-német gazdasági kapcsolatnak megfelelően a kulturális szótár számos (a magyar nyelvterületen is ismert) cég- és márkanevet tartalmaz: Adidas $A G, B M W$, DB, Grundig AG, Krupp, Lufthansa, Mozartkugel, Nescafé stb.

A betü- vagy mozaikszóból álló cégnevek feloldását (és ezzel gyakran a név magyarázatát) mindig megtaláljuk az adott szócikkben; pl. Aldi: az 'ALbrecht DIskont' rövidítése." $V W$ : Volkswagen, ,a népautót jelentő szó, az autómárka neve alighanem a legismertebb német szó a világon."

Címek nagy számban fordulnak elő a szótárban: föként sajtótermékek és irodalmi müvek címe; pl. Bild-Zeitung, Spiegel, Stern, FAZ. A folyóiratok nevét általában nem fordítja le a szótáríró: (Der) Spiegel „a legrégibb és legnépszerübb német hírmagazin, amely 1947 óta jelenik meg Hamburgban”, ugyanakkor a cím közszói jelentését közli: „Címe magyarul azt jelenti: 'A tükör'."

A müalkotások címei a német nyelvü irodalom különböző korszakait és müfajait reprezentálják: Erlkönig, Faust, Götz von Berlichingen, Hammerklaviersonate, Hildebrandslied, Kleiner Mann, was nun?, Merseburger Zaubersprüche stb.

A mücímek kategóriájának perifériáján megtalálható még a szótárban: der Heidelberger Chatekismus (,,a legfontosabb német evangélikus katekizmus”) vagy a Köchelverzeichnis (,Köchel-jegyzék”).

5.5. Olasz kulturális szótár. Olasz szempontból jelentős történelmi események nevei közül megtaláljuk a szótárban például a Grande Guerra címszót. A szócikk nem tartalmazza a név szó szerinti fordítását ('nagy háború'), csak a név magyarázatát: ,,az olasz szóhasználatban mindig az első világháborút jelenti”, majd ismerteti az I. világháború olasz szempontból jelentősebb eseményeit. A Risorgimento címszó melletti jelentés „szó szerint 'feltámadás' (de megkülönböztetendő Krisztusétól, amely resurrezione)"; ezt követi a részletesebb magyarázat: ,az olasz nemzet, illetve az ország területi és politikai egysége megteremtésének időszaka."

Az olasz kulturális szótárban is megtaláljuk intézmények, szervezetek neveit. Politikai szervezetek, pártok közül a Brigate Rosse nevet magyar megfelelöjével (Vörös Brigádok), olasz rövidítésével ( $B R$ ) és annak kiejtésével együtt. Jóval békésebb, aktuális szervezetként kapott a szótárban helyet az Alleanza Nazionale; a névnek itt nincs magyar megfelelője, csak egyfajta definíciója: ,jobboldali politikai párt”. A Forza Italia definíciója: „Silvio Berlusconi [...] által 1994-ben alapított, középjobb orientációjú erőket összekovácsoló mozgalom, majd párt." Megjegyzésként olvashatjuk a név jelentését: „Már a labdarúgó-mérkőzéseket felidéző neve is kész program (Hajrá Olaszország).”

Az intézménynevek között fontos szerepet játszanak a múzeumok nevei is. Az $A$-hoz besorolva találjuk az Ambrosiana címszót, mellette zárójelben az intézmény teljes nevét 
(Biblioteca e Pinacoteca Ambrosiana) és meghatározását: „,könyvtár és képtár Milánóban.” Sportszervezetek neveit is megtaláljuk a szótárban. Az Inter címszó után a teljes olasz név következik: Football Club Internazionale Milano, majd a név létrejöttének magyarázata: internazionale ('nemzetközi'), mert a klub a Milannal ellentétben külföldi játékosokat is szerződtetett.

A Barilla az egyik világszerte ismert olasz márka. A szócikk utal arra, hogy a cégnév és a márkanév megegyezik, bár a cégnek további márkái (és márkanevei) is vannak. Több jármümárka nevét is tartalmazza továbbá a szótár: Alfa Romeo, Ferrari, FIAT, Vespa stb. A FIAT esetében a szócikk megadja a betüszó feloldását (Fabbrica Italiana di Automobili di Torino), majd a legfontosabb típusokat (Balilla, Topolino), amelyekhez külön utalások vezetnek. A cég- és márkanév itt is egybeesik: „a legismertebb olasz gépkocsigyártó vállalat [...] és az általa gyártott autók neve.”

Sok különböző müfajú alkotás címe is megjelenik a szótárban. Természetesen filmcímek, például az Amarcord, amelynek szócikke nyelvi magyarázatot is tartalmaz: „Federico Fellini egyik leghíresebb filmjének [...] a címe romagnai dialektusban. Olaszul a mi ricordo, azaz 'emlékezem' igének felel meg." A Bambino di Roma egy szobor neve, amely a gyermek Jézust ábrázolja: ,,a leghíresebb ereklye Rómában.” A Pinocchio a szócikk meghatározása szerint: „Carlo Collodi (valódi nevén: Lorenzini) meseregénye.” Bár a mü teljes címe Le avventure die Pinocchio - Storia di un burattino, a címszó a főhős (fiktív) neve: Pinocchio. A többi kulturális szótárhoz hasonlóan az olasz is megemlékezik a nyelv nagyszótáráról. A Battaglia (,az olasz nyelv nagyszótára”) nevét szintén egykori föszerkesztőjéröl kapta.

A szótár az esetlegesen előforduló homonim címszavak esetében a következőképpen jár el. A Cinquecento ('500') az olaszban egyrészt köznév (?), az 1500-as évek, vagyis a 16. század elnevezése, másrészt egy ismert Fiat-típus (,hivatalosan Nuovo Cinquecento"), amely nevét $500 \mathrm{~cm}^{3}$-es motorjáról kapta. A szócikkben hangsúlyosan szerepel a tulajdonnévi használat, valamint az autómárka ipartörténeti jelentősége.

\section{Speciális kulturális szótárak}

6.1. Svájci kultúra németeknek. ÓDOR LÁSZLÓ (2010) Helvetismen [Helvétizmusok] címü kulturális szótára - a szerző ajánlása értelmében - egyrészt a nem svájci német nyelvüeknek szól, hogy jobban megértsék Svájcot, a svájci német nyelvjárást és a svájciakat, másrészt a svájciaknak, hogy jobban megértsék saját egyedülállóságukat, harmadrészt a magyaroknak is, „Európa örök vendégeinek”, hogy lássák, mindenütt vannak különbségek (ÓDOR 2010: V).

A szerző magyar-német szakot végzett bölcsész, aki 1990-1994 között Magyarország svájci nagykövete volt, de elötte és utána is a nemzetközi kapcsolatokkal foglalkozott; munkásságának alapvető eleme a kultúrkomparatisztika. Diplomáciai munkásságából táplálkozó szótára egynyelvü, alcíme szerint a svájci államszövetség német kulturális szótára.

Az elöbbiekben bemutatott szótárakkal összehasonlítva ez az egyetlen, amely nem szótárszerüen, két hasábba van tördelve, de a betürendbe szedett (svájci német) címszavai és azok (német) megfelelői, illetve magyarázatai egynyelvü szótárt alkotnak. A „szócikkek" sokszor egyetlen szóból, a standard német ekvivalensből állnak.

A szótárban számos földrajzi nevet találunk. Például vízrajzi neveket, mint az Aare, melynek rövid szócikke a folyó útját mutatja be Bern vidékétől a Rajnáig. A Freiburg városnév magyarázata is egyetlen mondatból áll: „,város és kanton a Kelet- és Nyugat-Svájc 
közötti nyelvhatáron.” Előfordul, hogy egy adott hely egy másik (nem német) nyelven ismertebb; ekkor a (korántsem közismert) svájci német megfelelö csak követi a közismert nevet: Lago Maggiore: Langensee.

A svájci szótárban alig-alig fordulnak elő személynevek. Közöttük Svájc történelmének jeles alakjait találjuk, szintén a családnevek (vagy névkiegészítők) szerint betürendbe sorolva: Winkerlied, Arnold: „,a svájci ügy önfeláldozó hőse”; Bruder Klaus: „Niklaus von Flüe, [...] a bölcs 15 . századi remete a mai átlagsvájci tartását, élet- és gondolkodásmódját fejezte ki” (a tanulmány szerzőjének fordítása).

Természetesen jellegzetes svájci szervezetek és pártok neveit is megtaláljuk a szótárban. Az FDP - a németországi betüszóval ellentétben - egy svájci párt nevének rövidítése: Freisinnig-demokratische Partei ('Szabadelvü Demokrata Párt'). Az LdU (Landesring der Unabhängigen: 'a függetlenek gyürüje') egy kelet-svájci párt neve; a párt központja Zürichben található. A Liga Rumantscha Svájc rétoromán lakosságának kulturális és politikai szervezetét jelöli; ekvivalens német nevet (pl. Rätoromanische Liga) nem ad meg a szótár. A svájci intézménynevek gyakran rövidítésükkel szerepelnek a szótárban, ezek feloldása adja meg a név magyarázatát; pl. TCS: „a svájci Touring Club rövidítése."

6.2. Egy város tulajdonnevei. LUKÁCS ANDRÁS 2018-ban megjelent római kulturális szótára nem egy nemzet vagy nyelv kultúráját igyekszik magyarázatokkal ellátni, hanem egy városét. A szótár tehát sok jellegzetesen római kifejezést (nyelvjárásit is) tartalmaz, emellett római hely- és épületneveket, intézmény- és személyneveket, valamint címeket is.

Az Accademia d'Ungheria in Roma intézménynév megfelelöje a Római Magyar Akadémia. A szócikk az intézet rövid történetét és helyszínét is bemutatja.

Ebben a szótárban is gyakoriak a rövidítések, pl. AS Roma: „teljes nevén Assoziazione Sportiva Roma [Róma Sportegyesület].” A betüszó feloldásán túl a köznyelvben használt névalakot is tartalmazza a szócikk: La Roma.

A fordítói szokásoknak megfelelően az uralkodók nevének pontos magyar ekvivalensét is megadja a szótár: Vittorio Emanuele II: II. Viktor Emánuel.

Róma kulturális örökségének megfelelően sok címszó nem olasz, hanem latin nyelvű. Ilyen pl. az „Ara Pacis teljes nevén Ara Pacis Augustae [...] 'Augustus békeoltára””. Az olasz címszót gyakran a latin megfelelő követi, mert az a magyarban is ismertebb. Így épül fel a Tevere szócikke, amelyben a címszó ekvivalense: ,latinban Tiberis, magyarban mind az olasz, mind a latin alak használata elfogadott."

A szótárban „meglepetésként” magyar címszó is található, a Triznya kocsma: „Triznya Mátyás (1922-1991) történész-festőmüvész és felesége, Szőnyi Zsuzsa (19242014) lakásán a hatvanas évektől egészen az ezredfordulóig vasárnaponként, majd később szombatonként rendszeresen összegyültek a magyar emigráció Rómában élő, illetve oda látogató tagjai."

7. Összefoglalás. A kulturális szótárak - mint egy speciális szótártípus képviselői - az egy- és kétnyelvü általános szótárakhoz képest sok tulajdonnevet tartalmaznak, hiszen az egyes országokra vonatkozó - leginkább kulturális - ismeretek átadásában a tulajdonnevek (az adott kultúra híres személyiségeinek és emblematikus helyszíneinek nevei, valamint a helyekhez, személyekhez köthető események elnevezése, intézmény- és márkanevek) kitüntetett szerepet kapnak. 
A kulturális szótárak tipikusan kétnyelvüek: a címszó „szokásos” esetben a forrásnyelven jelenik meg, míg definíciója, meghatározása, illetve körülírása, magyarázata célnyelven (jelen esetben: magyarul) olvasható, ugyanakkor a szócikkek tulajdonképpen az egynyelvü értelmező szótárak mintájára épülnek fel.

A kulturális szótárakban csak ritkán találunk 1 : 1 megfeleltetést (hozzárendelést), ami a többi szótárban a legáltalánosabb és elsődleges eljárásnak számít: „Käsmarkt 'Késmárk', a felvidéki szász város német neve (ma Kežmarok, Szlovákia)" (GYÖRFFY 2018: 148).

A kulturális szótárakban előforduló legtöbb tulajdonnévnek inkább definíció(szerü) értelmezése van, ennek tekinthetjük például, ha az Act of Union címszó mellett a következőket olvashatjuk: ,a parlament által 1707-ben hozott törvény [...], mely $\rightarrow$ Great Britain néven egységes királyságnak nyilvánította Angliát, Walest és Skóciát” (BART 2018: 11). Gyakori ez az eljárás a földrajzi neveknél: „Mariahilferstraße Bécs legnagyobb és legismertebb bevásárlóutcája, amely a magyar bevásárlóturizmus fő célpontja volt a Kádár-korszakban" (GYÖRFFY 2018: 191).

Más esetekben a tulajdonnév által jelölt fogalom elsődleges meghatározása nélkül, körülírás, magyarázat formájában ismerteti a szerző a címszó által megnevezett helyet, személyt, intézményt stb.: „Liberal Democratic Party 1988-ban alakult a $\rightarrow$ Labour Partyból kivált $\rightarrow$ Social Democratic Party (SDP) és a klasszikus $\rightarrow$ Liberal Party egyesülése révén" (BART 2018: 189).

A szótárak eltérő nyelvismeretet feltételeznek, illetve várnak el az olvasóktól. Sok esetben rövidebb-hosszabb idézetek is a névmagyarázat részét képezik, ezek az angol (BART 2018) és az amerikai (BART 2017) kulturális szótárban csak forrásnyelven olvashatók, a franciában (ÁDÁM 2005) azonban az idézeteket következetesen fordításuk követi szögletes zárójelben.

A kulturális szótárak szócikkeinek felépítése kevéssé emlékeztet a klasszikus szótárakéra: közös bennük, hogy kevés nyelvtani információt tartalmaznak, annál több leírást, magyarázatot. A nyelvtani információk közül a francia és az olasz szótár következetesen közli a fönevek nemét, míg a németben ez csak ritkábban jelenik meg, mert a német tulajdonnevek egyik fontos morfológiai jellegzetessége, hogy a nemüket eláruló névelő nélkül használják öket. Pl.

Arlecchino m. ,a commedia dell'arte egyik legjellegzetesebb alakja” (SZTANÓ 2008: 134), hímnemü;

Heure $f$. de verité (l’ ): „A közszolgálati France 2 tévécsatorna népszerü müsora" (ÁDÁM 2005: 119), nőnemü;

e Augsburger Bekenntnis, e Augustana: ,ágostai hitvallás” (GYÖRFFY 2018: 25), nőnemü.

A szócikkek helyenként a nevek pluralia tantum jellegére is utalnak, ha az eredeti (forrásnyelvi) tulajdonnevek többes számban használatosak, vagy így váltak tulajdonnévvé:

Halles (les ): „Az egykori vásárcsarnokot [...] 1853 és 1870 között építették" (ÁDÁM 2005: 118).

A szótárak a személyneveket általában (az adott forrásnyelvi névsorrendtől eltérően) a családnevekkel kezdődően közlik, pl. King, Jr. Martin Luther (BART 2017: 124), uralkodók 
esetén a keresztnév a cím előtt áll, pl. Albert, Prince (BART 2018: 13, az olasz szótárban azonban Regina Elena (SZTANÓ 2008: 239), Papa Lambertini (SZTANÓ 2008: 207).

A kulturális szótárakban a tulajdonnevek közvetítésének (VERMES [2005] osztályozása szerinti), illetve a tulajdonnévpárok tagjai közötti kapcsolatnak mind a négy típusával találkozhatunk. (A szótárakban szereplő szócikkek címszavai természetesen nem szövegekbe ágyazva jelennek meg, így csak a szócikkek felépítéséböl következtethetünk a közvetítés lehetséges fajtájára.)

Átvitt név esetén az eredeti (forrásnyelvi) tulajdonnév átvitel útján, változatlan alakban jelenik (jelenne meg) meg a célnyelvben a célnyelvi névforma nélkül (már ha létezik ilyen), a szótárak definiálást vagy körülírást alkalmaznak. Pl. Suhrkamp: ,,a legtekintélyesebb német nyelvü szépirodalmi és társadalomtudományi könyvkiadó Frankfurt am Mainban.” A szótárakban gyakran találkozunk átvitellel üzlet- és márkanevek esetében.

Behelyettesítésnek tarthatjuk, amikor a forrásnyelvi tulajdonnév konvencionális (történetileg alakult) célnyelvi megfelelöje jelenik meg a szócikkben. Ez különösen gyakori a célnyelvi nyelvhasználó közösség számára többé-kevésbé ismert (vagy akár a közösségek számára „közös”) földrajzi nevek esetében. Pl. Thüringen: „Türingia” (GYÖRFFY 2018: 293). A célnyelvi megfelelő (különösen az olasz szótárakban) néhány esetben más nyelvből kölcsönzött; pl. Adriano: „latinul és magyarul Hadrianus” (LUKÁCS 2018: 9). Hagyományosan ide tartoznak az uralkodók (pápák) nevei is.

Szükebb értelemben vett fordítást találunk általában a (több szóból álló) intézményneveknél, amikor a forrásnyelvi tulajdonnév lexémáit többé-kevésbé pontosan, de a célnyelv morfológiai-szintaktikai szabályainak figyelembevételével célnyelvi megfelelökkel helyettesítjük: Accademia d'Ungheria in Roma: „Római Magyar Akadémia” (LUKÁCS 2018: 7), SPD: Sozialdemokratische Partei Deutschlands: Német Szociáldemokrata Párt" (GYÖRFFY 2018: 279).

Modifikációt feltételezünk azon névpároknál, ahol a célnyelvi megfelelő konvencionálisan nem áll kapcsolatban a forrásnyelvivel, csak annak funkcióját jelzi. Pl. Signor Bianchi: „Kovács úr, azaz a tökéletesen átlagos ember” (SzTANÓ 2008: 262).

A fenti eljárások egy-egy név esetében keveredhetnek is (vö. LuKÁcs 2012): Barbarossa: „Rőtszakállú ( $\rightarrow$ Rotbart) I. Frigyes”, a Frigyes behelyettesítés, a Rőtszakállú szükebb értelemben vett fordítás eredménye.

Mint láttuk, a kulturális szótárak olyan enciklopédikus lexikográfiai müvek, amelyek az egyes idegen nyelvek és nyelvhasználó közösségeik fontos és/vagy jellegzetes kulcsszavait tartalmazzák, amelyek nem elhanyagolható része tulajdonnév. Ezen tulajdonnevek bemutatása a vizsgált szótárakban éppoly különböző, mint a lemmaállomány kiválasztásának szempontjai, a tulajdonnevek nyelvi közvetítésének elvei azonban a legtöbb esetben megfelelnek a fordítási hagyományoknak.

\section{Felhasznált források}

ÁDÁM PÉTER 2005. Francia-magyar kulturális szótár. 2. kiadás. Corvina Kiadó, Budapest.

BALOGH F. ANDRÁs 2017. Német-magyar kulturális szótár. Szász, sváb, landler, cipszer és bukovinai német nyelvü kultúra a történelemben és mindennapokban. Anyanyelvápolók Erdélyi Szövetsége, Sepsiszentgyörgy.

BART, ISTVÁN 2005. La Hongrie et les Hongrois. Magyar-francia kulturális szótár. Corvina Kiadó, Budapest. 
BART, ISTVÁN 2015. Hungary \& The Hungarians. Magyar-angol kulturális szótár. 4. kiadás. Corvina Kiadó, Budapest.

BART, IstVÁN 2016. Ungarn Land und Leute. Magyar-német kulturális szótár. 3. kiadás. Corvina Kiadó, Budapest.

BART IsTVÁn 2017. Amerikai kulturális szótár. 2. kiadás. Corvina Kiadó, Budapest.

BART IsTVÁN 2018. Angol kulturális szótár. 3. kiadás. Corvina Kiadó, Budapest.

BENÖ ATTILA 2009. Román-magyar kulturális szótár. Anyanyelvápolók Erdélyi Szövetsége, Sepsiszentgyörgy.

PÉNTEK, JÁNOS - BENŐ, ATTILA 2013. Dicționar cultural maghiar-român. Anyanyelvápolók Erdélyi Szövetsége, Sepsiszentgyörgy.

GYÖRFFY MiKLÓs 2018. Német kulturális szótár. 2. kiadás. Corvina Kiadó, Budapest.

Gy. HoRVÁTH LÁszLÓ 2018. Japán kulturális szótár. 2. kiadás. Corvina Kiadó, Budapest.

LUKÁCS ANDRÁs 2018. Róma. Kulturális szótár. Corvina Kiadó, Budapest.

ÓDOR, LÁSZLó 2010. Helvetismen. Deutsches Kulturwörterbuch der Schweizerischen Eidgenossenschaft. Martin Meidenbauer Verlagsbuchhandlung, München.

ÓDOR LÁSZLÓ 2016. Új német-magyar olvasmányos kulturális szótár esszé. K. n., h. n.

SOPRONI ANDRÁs 2008. Orosz-magyar kulturális szótár. Corvina Kiadó, Budapest.

SZTANÓ LÁSZLó 2008. Olasz-magyar kulturális szótár. Corvina Kiadó, Budapest.

\section{Hivatkozott irodalom}

FÁBIÁN ZSUZSANNA 2015. A szótár, illetve a lexikon és az enciklopédia megkülönböztetése az „enciklopédikus szótár” müfajának tükrében. In: FÁBIÁN ZSUZSANNA - SzÖLLÖSY ÉVA szerk., Szótár, lexikon, enciklopédia. Kérdések és feladatok. Segédkönyvek a nyelvészet tanulmányozásához 172. Tinta Könyvkiadó, Budapest. 17-38.

KLAUDY KINGA 1994. A forditás elmélete és gyakorlata. Angol, német, francia, orosz forditástechnikai példatárral. Scholastica Kiadó, Budapest.

Klosa, ANNETTE - SCHNÖRCH, UlRICH - Schoolaert, SABINE 2010. Stichwort, Stichwortliste und Eigennamen in elexico. In: DyKSTRA, ANNE - SCHOONHEIM, TANNEKE szerk., Proceedings of the XIV EURALEX International Congress. 6-10 July 2010. Fryske Akademy - Afûk, Leeuwarden/Ljouwert. 653-663. http://www.euralex.org/elx proceedings/Euralex2010/052 Euralex_2010_3_KLOSA\%20SCHNORCH\%20SCHOOLAERT_Stichwort, $\% 20$ Stichwortliste $\% 20$ und $\% 20$ Eigennamen $\% 20$ in $\% 20$ elexiko_Einflusse $\% 20$ der $\% 20$ Korpusbas.pdf (2020. 05. 02.)

LUKÁCS ANDRÁs 2010. A kulturális szótár mint müfaj. Forditástudomány 12/1: 38-49.

LUKÁCS ANDRÁS 2012. Müfajspecifikus megfeleltetési stratégiák az útikönyvek forditásában. Doktori $(\mathrm{PhD})$ értekezés. ELTE, Budapest. Kézirat. http://doktori.btk.elte.hu/lingv/lukacsandras/diss.pdf (2020. 05. 02.)

MAGAY TAMÁs 2015. Szótár, enciklopédia és tipológia. In: FÁBIÁN ZSUZSANNA - SZÖLLŐSY ÉVA szerk., Szótár, lexikon, enciklopédia. Kérdések és feladatok. Segédkönyvek a nyelvészet tanulmányozásához 172. Tinta Könyvkiadó, Budapest. 9-16.

SCHMIDT, BERNHARD et al. 2006. Frankreich-Lexikon. Schlüsselbegriffe zu Wirtschaft, Gesellschaft, Politik, Geschichte, Kultur, Presse- und Bildungswesen. Zweite Ausgabe. Erich Schmidt Verlag, Berlin.

VALLÓ ZSUZSA 2000. A fordítás pragmatikai dimenziói és a kulturális reáliák. Forditástudomány 2/1: 34-49. 
VERMES AlBert PÉTER 2005. Proper names in translation. A relevance-theoretic analysis. Névtani Értesítö 27: 311-314.

SZILÁGYI-KÓSA ANIKÓ

ORCID: https://orcid.org/0000-0003-4680-105X

Károli Gáspár Református Egyetem

Bölcsészet- és Társadalomtudományi Kar

\section{ANIKó SZILÁGYI-KóSA, Proper names in cultural dictionaries}

The study examines the occurrence of proper names in cultural dictionaries based on a few examples. The genre of cultural dictionary is relatively new and particularly Hungarian. These dictionaries are bilingual, specialized dictionaries that present the culturally bound vocabulary of particular (source) languages, often taking into account the interests and knowledge of the target language readers. In the dictionaries selected for analysis (English, American, French, German, and Italian), the proportion of proper names ranges from approximately $30 \%$ to $60 \%$. There are many types of proper names. These can be grouped into three categories: toponyms, anthroponyms, and other names (of institutions, brands, etc.). On the one hand, the cultural dictionaries contain very little grammatical information in the entries of proper names. On the other hand, there are several definitions, descriptions, while ways of transmitting names (unchanged transfer, replacement, translation, and modification) can also be encountered. 